Hydrol. Earth Syst. Sci. Discuss.,

https://doi.org/10.5194/hess-2020-269-RC1, 2020

(c) Author(s) 2020. This work is distributed under

the Creative Commons Attribution 4.0 License.

\section{Hydrology and Earth System Sciences

\title{
Interactive comment on "New flood frequency estimates for the largest river in Norway based on the combination of short and long time series" by Kolbjørn Engeland et al.
}

\section{Anonymous Referee \#1}

Received and published: 20 July 2020

\section{See pdf file}

Please also note the supplement to this comment:

https://www.hydrol-earth-syst-sci-discuss.net/hess-2020-269/hess-2020-269-RC1-

supplement.pdf

Interactive comment on Hydrol. Earth Syst. Sci. Discuss., https://doi.org/10.5194/hess-2020- 